\title{
Small-Scale Industries Development Strategy in Bitung City Using SWOT Analysis and TOWS Strategy
}

\author{
Stanny Sicilia Rawung * (D), and Maya F. S. Salindeho \\ Department of Economics, Faculty of Economics, \\ Universitas Negeri Manado, 95618, North Sulawesi Province, Indonesia \\ * Corresponding Author: stannyrawung@unima.ac.id
}

\section{ARTICLE INFO}

\section{Publication Info:}

Research Article

How to cite:

Rawung, S. S., E Salindeho, M. F.

S. (2020). Small-Scale Industries

Development Strategy in Bitung

City Using SWOT Analysis and

TOWS Strategy. Society, 8(2),

783-793.

DOI: $10.33019 /$ society.v8i2.269

Copyright @ 2020. Owned by Author(s), published by Society

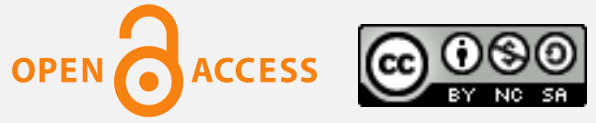

\begin{abstract}
This study aims to analyze industrial groups' position based on developing and business success and strategies that can be used in developing small-scale industrial enterprises in the Bitung City, North Sulawesi Province. The research took place in Bitung City, North Sulawesi Province. The research sample was 185 small business owners in Bitung City. The sampling method used was random. Data were collected using a questionnaire with a Likert scale and strategy analysis using SWOT analysis and TOWS strategy. The results of this study found that: (1) based on the SWOT analysis results, each industry group is advised to implement a survival strategy and future integration that is offered according to internal factors and external factors that affect the success of micro-businesses in Bitung City. (2) the small-scale industries in Bitung City have excellent development capabilities and a high business success level.
\end{abstract}

This is an open-access article.

License: Attribution-

NonCommercial-ShareAlike (CC BY-NC-SA)

Received: November 29, 2020; Accepted: December 28, 2020; Published: December 31, 2020;

Keywords: Business Development Strategy; Small-Scale Industry; SWOT; TOWS

Copyright (C) 2020. Owned by Author(s), published by Society. This is an open-access article under the CC-BY-NC-SA license. 


\section{Introduction}

The small industrial sector is one of the crucial locomotives for economic development and growth in various countries in the world (Gumelar, 2015). Small and household industries have three important reasons that underlie their existence in Indonesia. First, small and household industries' performance tends to be better in producing productive labour. Second, as part of its dynamic, small and household industries often achieve increased productivity through investment and technological changes. Third, because it is often believed that small and household industries have an advantage in flexibility over large businesses (Fatria, 2017).

The Government fully supports Industries: Strategic: National Resilience \& National Competitiveness, Responsible is the National Level (formerly a kind of BPIS Industry). Main Industry (based on Agro and Natural Resources Products, including clothing, food and shelter), its development is not just primary industry. Still, it is developed more in the secondary industry (manufacturing/process). The supporting industry is an industry-developed to support strategic and major industries, both the manufacturing and service industries (including education) (Prapton, 2009).

The absorption of labor in the small industrial sector contributes to regional and national income and impacts the Indonesian economy. Even so, the competitiveness of small industries is still low. Kuncoro (2007) considers that the small industry development role is very large in the industry's development. By using labor-intensive technology, employment and business opportunities can be even greater. Apart from encouraging regional development and industrial estates, this is certainly one solution to the ongoing unemployment problem.

In the North Sulawesi Spatial Planning, the North Sulawesi Provincial Government has designated several industrial estates in regency cities, one of which is Bitung City. Presidential Decree No. 59 of 1989 explains that an industrial area is a center for the processing industry, supported by facilities, infrastructure, and various other supporting facilities provided and managed by the company in the industrial area (Republik Indonesia, 1989).

The development of industry in North Sulawesi Province, especially in Bitung City, has made encouraging progress in line with the increase in the number of business units, labor, and the resulting investment value (Badan Pusat Statistik Kota Bitung, 2018). Besides, various types and industrial products that have also developed and various achievements in the industrial sector, on a national or regional scale, are also evidence of the rapid progress of the industrial world in Bitung City.

In North Sulawesi Province, $68 \%$ or most of them are included in the Small-scale Industry category. However, in terms of production value, compared to large industries that employ $40 \%$ of the workforce and reach IDR 19.7 trillion in value, the achievement of the value of small industry production is still only IDR 3.8 trillion with $60 \%$ of the workforce (Kantor Wilayah Departemen Perindustrian dan Perdagangan Provinsi Jawa Timur, 2001). Sulut Alwy, Head of Small and Medium Scale Industry (SMSI) Development, the Ministry of Industry and Trade, stated that for SMSIs that obtain business legality from the target of 225 Micro and Small Business Permits, the realization would be 250 permits. Meanwhile, SMSI, which received quality certification facilitation, namely Halal and PIRT (Food Home Industry), from the 120 Certificates, 132 certificates' target could be realized.

In producing production volume, small industrial businesses usually experience various obstacles that cause low income, including small businesses in Bitung City. They must have the guts to compete with other industries, medium-sized industries, and large industries. Large industries will be easier to develop because they have large capital and sophisticated technology, while small industries have limited capital and technology. This, of course, will

Copyright (C) 2020. Owned by Author(s), published by Society. This is an open-access article under the CC-BY-NC-SA license.

https://doi.org/10.33019/society.v8i2.269

784 
lead to unfair competition. So, cooperation or partnerships between small, medium, and large industries need to be built to develop small industries. By sticking to the principles of mutual strengthening, benefit, and necessity, medium, and large businesses are expected to foster and help develop small businesses through such cooperation or partnerships. Large industries can help by marketing small industrial products or supplying supporting tools and raw materials from small industries. Therefore, it is necessary to examine how the strategies used to develop small industrial businesses in Bitung City use the SWOT method to analyze the most suitable strategies for small entrepreneurs in North Sulawesi.

\section{Research Methodology}

Cooper \& Emory (1996) define research design as a plan used to select sources and types of information in answering research questions. The research design can be grouped into eight based on the perspective, namely: (1) the degree to which the research problem is formulated, (2) data collection methods, (3) the researcher's ability to generate the impact of research variables, (4) research objectives, (5) time dimensions, (6) the scope of the research topic, (7) the research environment, and (8) the subject's perception of the research. In the end, the research design will answer questions about data collection techniques, sampling, and how to overcome time and cost constraints.

\subsection{Research Location}

This research was conducted in Bitung City, North Sulawesi, Indonesia.

\subsection{Population and Research Sample}

\subsubsection{Research Population}

The population is the totality of objects or individuals to be studied, with certain characteristics that are clear and complete (Hasan, 2006). Small industrial entrepreneurs in Bitung City are the population in this study. There are 344 Small Industry units, according to the Bitung City Industry, Trade, and Cooperative Office. Nasution (2000) stated that there is no limit to the number of samples from the population for a study. However, researchers used analytical tools in determining the sample for this study.

\subsubsection{Research Samples}

The following stages were carried out to determine the sample of this research:

a) Collecting data on the total population. Data collection was carried out on the number of small businesses in Bitung City.

b) Small industrial business owners who are domiciled in the city of Bitung are the samples in this study.

Three hundred forty-four small industrial entrepreneurs in Bitung City were sampled in this study obtained from the target population. The random sampling method is used as a sampling method (Sugiyono, 2006). The Yamane formula is used to determine the minimum sample size (Rakhmat, 1997):

$$
n=\frac{N}{N d^{2}+1}
$$


Information:

$\mathrm{n}=$ sample size

$\mathrm{N}=$ population size

$\mathrm{d}=$ bound of error

Guided by research in economics, this study's bound of error is $5 \%$ or 0.05 . That way, to calculate the sample size is:

$$
\mathrm{n}=\mathrm{Bu}_{1+344(0,05)^{2} \quad 344_{-}=184,946}
$$

The calculation formula above produces the minimum sample size used is 185 people.

\subsection{Data Analysis Techniques}

A SWOT analysis is used to analyze the strategy for developing small-scale industrial enterprises in general (Permadi, 2015). The TOWS strategy and the next step formulate a development strategy according to each industry group using the Likert scale calculation results for each variable and indicator.

\subsection{Business Development Strategy}

The company's strategy to succeed in the main competition requires them to make a strategy by paying attention to their resources. Strategies provide us with a balance of direction and orientation and flexibility in adaptation to the environment. In general, successful strategies are obtained from several things based on careful planning previously done (Nurdjannah, 2006).

1) Simple long term goals

The business strategy should contain clear goals to provide stability and unity in the company's direction. With clear, consistent goals and remain oriented towards shareholders, employees, and consumers' responsibilities, the desired results will be easily achieved.

2) Analysis of the competitive environment

The changing needs of consumers need to be identified to determine the market position by understanding the stock market valuation and potential acquisition possibilities. Besides, the ability to identify and motivate all human resources in the company is equally important.

3) Objective resource assessment

These aspects include the company's awareness of its resources and potential, product reputation and brand, the ability to encourage employees, handling effective partnerships with suppliers, and handling and quality control capabilities.

4) Effective implementation

The most appropriate strategy requires effective implementation. Leadership with a qualified organizational structure and management system is needed for good corporate commitment and regular coordination and resource mobilization. 


\subsection{SWOT analysis (Strengths, Weaknesses, Opportunities, Threats)}

Rangkuti (2009) stated that analysis systematically analyzes various factors in formulating corporate strategy. SWOT analysis is an analysis based on logic, maximizing strengths and opportunities, and at the same time minimizing weaknesses and threats.

The research uses SWOT as an analysis tool because, from previous research results, it was found that in planning something, SWOT analysis is often used to consider all potentials and possibilities that arise. In this way, the effectiveness of planning is easier to measure. Strategic planning is needed to manage and develop an activity, such as goals or patterns that support and complement each other towards a comprehensive goal. Therefore, sharp analysis and determination of the right strategy are needed to form programs and project activities that are effective and efficient, in this case. SWOT analysis is one analysis that is quite widely used.

In addition to designing the company's strategic factors, the SWOT matrix can also describe its opportunities and external threats without neglecting the existing strengths and weaknesses. This matrix generates four possible sets of strategic alternatives.

a. S-O (Strengths-Opportunities) Strategy

Rangkuti (2009, p. 31) stated that this strategy optimizes all its strengths and opportunities as much as possible.

Umar (2003, p. 225) also revealed that the company's internal strength is the power used to take opportunities outside the company in this strategy.

b. S-T (Strengths-Threats) Strategy

Rangkuti (2009, p. 31) argues that the S-T Strategy uses company strength to overcome threats. This strategy is intended to take advantage of external opportunities to minimize company weaknesses (Umar, 2003, p. 225).

c. W-O (Weaknesses-Opportunities) Strategy

This strategy takes advantage of opportunities by minimizing weaknesses (Rangkuti, 2009, p. 31). This strategy allows companies to minimize deeds that arise from external threats (Umar, 2003, p. 225).

d. W-T (Weaknesses-Threats) Strategy

This strategy is defensive about minimizing weaknesses and avoiding threats (Rangkuti, 2009). This is a defense tactic by suppressing internal weaknesses and avoiding threats (Umar, 2003). Companies can be said to be in a dangerous position when faced with internal weaknesses and external threats.

\section{Results and Discussion}

\subsection{Small-Scale Industry Development Strategy in Bitung City}

From the analysis results, to set a strategy for small-scale industrial development in Bitung City, the first step taken was to identify internal factors in the form of existing strengths and weaknesses and external factors in the form of opportunities and threats to small-scale industrial development.

Internal factors that are the strength of small industries in Bitung City are its strategic location, experienced local workers, accessibility barriers such as transportation and telecommunications, products with licenses from the Industry and Trade Service, and the Health Service for the food industry. 
This study also found consumers less recognize internal factors which are weaknesses for small industries in Bitung City, namely the lack of attractive label design, logos and packaging, company products due to lack of promotional activities, limited business capital, simple financial accounting, and reporting, equipment in production still simple, lack of human resources in research and development, and the company has not conducted research and development activities.

From the analysis results then identify the Opportunity and Threaths Factors $(\mathrm{O}-\mathrm{T})$ which is reflected in the matrix below:

Table 1. Small-Scale Industry Development Matrix in Bitung City, North Sulawesi Province

\begin{tabular}{|c|c|c|}
\hline INTERNAL & $\begin{array}{l}\text { O (Opportunities) } \\
\text { 1. The improvement of economic } \\
\text { growth in Bitung City. } \\
\text { 2. Many events, both national } \\
\text { and international in North } \\
\text { Sulawesi, have had a positive } \\
\text { impact. } \\
\text { 3. Population growth continues } \\
\text { to increase. } \\
\text { 4. Bitung City is an industrial and } \\
\text { maritime city known as the } \\
\text { vision and mission of the } \\
\text { Bitung City. } \\
\text { 5. There is support from the } \\
\text { government in the form of a } \\
\text { revolving fund. } \\
\text { 6. Easy provision of loans/credit } \\
\text { from banks for small } \\
\text { industries. }\end{array}$ & $\begin{array}{l}\text { T (Threaths) } \\
\text { 1. The absence of small } \\
\text { business associations } \\
\text { capable of fostering } \\
\text { cooperation, resulting in } \\
\text { tight competition for } \\
\text { similar companies. } \\
\text { 2. The bargaining power of } \\
\text { suppliers is high. } \\
\text { 3. The high bargaining power } \\
\text { of consumers. } \\
\text { 4. The emergence of a similar } \\
\text { industry. }\end{array}$ \\
\hline S (Strengths) & S-O STRATEGY & S-T STRATEGY \\
\hline $\begin{array}{l}\text { 1. The strategic location of the } \\
\text { industry. } \\
\text { 2. The use of experienced local } \\
\text { human resources. } \\
\text { 3. There are no obstacles in } \\
\text { transportation or } \\
\text { telecommunications. } \\
\text { 4. The product already has a license } \\
\text { from the industry and trade } \\
\text { service and the health office for the } \\
\text { food industry. }\end{array}$ & $\begin{array}{l}\text { 1. Increase production capacity } \\
\text { by taking advantage of } \\
\text { strategic locations. (S1, S2, S3, } \\
\text { O1, O2, O3, O4, O5, O6 } \\
\text { 2. Maximizing distribution } \\
\text { channels to increase sales } \\
\text { results. (S1, S4, O1, O2, O3, O4, } \\
\text { O5, O6) }\end{array}$ & $\begin{array}{l}\text { 1. Making a product } \\
\text { innovation with a } \\
\text { differentiation method so } \\
\text { that the advantages of each } \\
\text { industry are clear. (S1, S2, } \\
\text { S3, S4, T4) } \\
\text { 2. Maximizing new supplier } \\
\text { channels and distribution } \\
\text { channels to bring up a } \\
\text { variety of alternative } \\
\text { suppliers and new } \\
\text { consumers. (S1, S3, S4, T1, } \\
\text { T2) good quality } \\
\text { 3. Creating grods } \\
\text { products registered with } \\
\text { ISO and SNI. (S3, S4,) }\end{array}$ \\
\hline
\end{tabular}

Copyright ( $(2020$. Owned by Author(s), published by Society. This is an open-access article under the CC-BY-NC-SA license. https://doi.org/10.33019/society.v8i2.269 


\section{W (Weaknesses)}

1. The appearance of labels, logos, and packaging is less attractive.

2. Lack of product promotion so that potential consumers are less recognized.

3. Limited working capital and simple financial accounting and reporting.

4. The equipment is still simple in production and does not yet have personnel in the R\&D sector.

5. Research and development have not been done.

\section{W-O STRATEGY}

1. Redesign the packaging and make it more attractive, especially when there are events at the provincial level. (W1, O1, O2, O3, O4, O5, O6)

2. Sponsoring tourism activities. (W1, O2, O3, O4, O5, O6)

3. Take advantage of government assistance and credit to increase working capital. (W1, W4, O5, O6)

\section{W-T STRATEGY}

1.

1.Improve

financial management and allocation (W3, W4, T1, T2, T3)

2. Enter into contracts with suppliers regarding the procurement of raw materials. (W5, T1, T2)

Collaborating government with institutes or academics. (W1, W2, W3, W4, W5, T4)

Based on the analysis results, several external strategic factors constitute the opportunities and threats of small industries in Bitung City. The external factors that become these opportunities are economic growth that is getting better, and there are many events in North Sulawesi that have an impact on Bitung City, increased population growth, the recognition of Bitung City as an industrial and maritime city, government support with government policies and programs in the form of provision of revolving funds, ease of providing loans/credit from banks.

Besides, this study also found that external factors that pose a threat are the absence of small business associations that are deemed capable of inviting them to cooperate, competition from similar companies can occur, high bargaining power of suppliers and consumers, and the growth of similar industries. This then becomes a guideline to make several strategies for the development of small industrial businesses in the Bitung City as described below:

1. S-O Strategy

Maximizing distribution channels to increase sales volume. In marketing activities, distributors play a significant role in optimizing distribution channels. The relationship created between industry and intermediaries will impact increasing production capacity, for example, by providing full service during transactions, such as the fulfillment of the number of orders, price stability, guaranteed guarantees always so that buyers are always satisfied.

2. W-O Strategy

Creating or redesigning special packaging, especially during a local event. The creation of special edition packaging is intended so that the products produced to get the attention of migrants from various corners.

Besides, the product becomes more recognizable, and small entrepreneurs should participate as sponsors of these tourism events by distributing pamphlets and brochures.

The next thing is to develop the business by making the best use of assistance in the form of revolving funds provided/channeled by the Government through Cooperatives and Micro, Small and Medium Enterprises Office.

Limited capital is also an obstacle to business development. For this reason, small industries in Bitung City can take advantage of the offer of government assistance and bank credit as well as possible. 
Small industries in Bitung City can increase their production capacity with adequate capital, modernize tools to shorten the production process, improve product quality, develop/diversify products, improve product quality, and organize a reliable workforce to manage business management.

\section{S-T Strategy}

Quality improvement and product innovation also need to be carried out to increase product competitiveness. High industrial competition and small entry barriers for new competitors require small industries to retain consumers by maintaining or improving product quality. Good coordination between owners and employees as well as a skilled and experienced workforce is essential. Meanwhile, increasing product quality control can be done by sorting out the main raw materials to be used, maintaining the hygiene of the production process, maintaining good quality and good and neat packaging.

Thus, product quality will always be guaranteed, and buyer loyalty will increase if the product already has a license, either from the Industry and Trade Service or the Health Service. Besides that, it makes good quality products by registering with ISO and SNI.

\section{W-T Strategy}

Improve financial management and allocation. These improvements are needed to overcome problems, for example, if there is an increase in the price of raw materials by separating family finances and company finances. Purchasing raw materials should also be done in large quantities to get a relatively low price, and for industries that still use kerosene, they should switch to using LPG gas to save production costs.

The existence of good financial arrangements will greatly help competition with similar industries. The alternative strategy chosen is market penetration, market development, product development and backward integration.

The second thing is to enter into contracts or cooperate with large industrial industries of the same type in branding and marketing. It is hoped that the collaboration with large industries will help small industries in marketing their products with brands that are well known to the public. Thus, large industries help small industries in branding and marketing, which is expected to increase sales.

The alternative strategy chosen is a forward integration strategy. Furthermore, it can collaborate with government research institutions and academics.

This study also found that using the SWOT matrix in formulating alternative strategies resulted in several alternative strategies for developing small industrial businesses in Bitung City by prioritizing the use of assistance from the government and bank credit, product diversification, product diversification, product development, and promotion through existing events, nationally and internationally, as well as integrating with major industries in terms of branding and marketing.

From the results of the Likert scale in this study, it can be seen that the distribution of values in each industrial group: 
Table 2. Small Industrial Businesses' Capability to Develop and Succeed

INDUSTRY SECTOR

BUSINESS CAPABILITIES
BUSINESS SUCCEED

\begin{tabular}{|lcc|}
\hline 1. Food & 2.93 & 4.33 \\
\hline 2. Chemical & 2.15 & 4.07 \\
\hline 3. Metal & 2.88 & 4.33 \\
\hline 4. Crafts & 2.7 & 4.07 \\
\hline
\end{tabular}

Furthermore, the research also connects the results of the distribution of value with the stages of strategy formulation in each business unit so that it will make the industry more optimal when running its business, including:

1) Look into the business and find out what the "Competitive Advantage" it has. The goal is to recognize the strengths and advantages of competing with other products with their respective advantages.

2) By knowing the position of each sector regarding the ability to develop and business success, the company will not be trapped by the conditions it is experiencing and will continue to be able to develop its business.

3) Formulating an effective strategy.

Not all strategies can be created and implemented to achieve company goals. There is no such thing as a good or bad strategy, but the formulation and implementation need to consider the needs and culture of the industry.

Industry owners can only formulate an effective strategy because they better recognize weaknesses and details about their business.

Based on the distribution of values that exist in each industrial sector, alternative strategies can be made for each industrial sector as follows:

1) Food Industry
a. Increase Workforce Ability
b. Improve product quality
c. Increase HR creativity

2) Chemical and Building Industry
a. Management system improvement
b. Strengthening capital by cooperating with related agencies/banking and even government agencies
c. Increase HR creativity
d. Improve the quality of human resources

3) Metal and Electronic Industry
a. Strengthening capital using government assistance and even working with banking institutions
b. Improve the management system

4) Craft Industry
a. Strengthening Capital
b. Improve the quality of human resources

Copyright (C) 2020. Owned by Author(s), published by Society. This is an open-access article under the CC-BY-NC-SA license. 
c. Increase HR Creativity

d. Establish the right Market strategy

\section{Conclusion}

The study found that the industry in North Sulawesi used the strategy of survival and forward integration offered by adjusting the factors that influence the success of the microindustry business in Bitung City. Every existing industrial sector must be able to develop its business better.

The results showed that each industry in Bitung City has an excellent business development capacity with a high level of business success. The government is expected to continue encouraging, whether in funding, marketing, promotion, or research activities.

\section{Acknowledgment}

The authors are grateful to express gratitude to those who have had the pleasure to cooperate during this study.

\section{Declaration of Conflicting Interests}

The authors have declared no potential conflicts of interest concerning the study, authorship, and/or publication of this article.

\section{References}

Badan Pusat Statistik Kota Bitung. (2018). Kota Bitung Dalam Angka 2018. Retrieved from https:// bitungkota.bps.go.id/publication/2018/08/16/6b293526a4c84179bd3d37fd/kot a-bitung-dalam-angka-2018.html

Cooper, D. R. \& Emory, C. W. (1996). Metode Penelitian Bisnis. Jakarta, Indonesia: Erlangga.

Fatria, M. A. (2017). Strategi Pengembangan Industri Rumah Tangga di Kota Pekanbaru (Studi Kasus Usaha Jamur Crispy Industri Pengolahan Jamur Tiram). Jurnal Online Mahasiswa Fakultas Ekonomi, 4(1), 283-297. Retrieved from https://jom.unri.ac.id/index.php/JOMFEKON/article/view/12291

Gumelar, B. (2015). Strategi Pengembangan Industri Kecil Kripik Tempe Di Desa Karangtengah Prandon Kabupaten Ngawi (Studi Pada Dinas Koperasi, Usaha Mikro Kecil Menengah Dan Perindustrian Kabupaten Ngawi). Jurnal Administrasi Publik, 3(1), 55-60. Retrieved from

http://administrasipublik.studentjournal.ub.ac.id/index.php/jap/article/view/742

Hasan, I. (2006). Analisis Data Penelitian dengan Statistik. Jakarta, Indonesia: Bumi Aksara.

Kantor Wilayah Departemen Perindustrian dan Perdagangan Provinsi Jawa Timur. (2001). Sekilas Perkembangan Industri Kecil dan Kinerja Ekspor Jawa Timur Tahun 1999-2000. Departemen Perindustrian dan Perdagangan.

Republik Indonesia. (1989). Keputusan Presiden Republik Indonesia Nomor 53 Tahun 1989 Tentang Kawasan Industri.

Kuncoro, M. (2007). Ekonomika industri Indonesia. Yogyakarta, Indonesia: CV. Andi Offset. Nasution, S. (2000). Metode Research. Jakarta, Indonesia: Bumi Aksara.

Nurdjannah. (2006). Perencanaan Strategi Pengembangan. Retrieved from http://www.tumoutou.net/mm_ku/sm/0667/nurdjannah.pdf

Permadi, A. (2015). Strategi Pengembangan Industri Kecil Carica. Jurnal Ekonomi dan Kebijakan, 8(1), 45-53. https:/ / doi.org/10.15294/jejak.v8i1.3853 
Prapton, B. (2009). Strategi Pengembangan Industri di Indonesia. Retrieved from https:/ / budipraptono.wordpress.com/2009/09/18/strategi-pengembangan-industri-diindonesia/

Rakhmat, J. (2007). Psikologi Komunikasi. Bandung, Indonesia: Remaja Rosdakarya.

Rangkuti, F. (2009). Analysis SWOT: Teknik Membedah Kasus Bisnis. Jakarta, Indonesia: Gramedia Pustaka Utama.

Sugiyono. (2006). Metode Penelitian Kuantitatif Kualitatif dan RED. Bandung, Indonesia: Alfabeta. Umar, H. (2003). Metode Riset Perilaku Organisasi. Jakarta, Indonesia: Gramedia Pustaka Utama.

\section{About the Author}

1. Stanny Sicilia Rawung obtained her Doctoral degree in Economics from Universitas Hasanuddin, Indonesia, in 2014. The author is an Assistant Professor at the Department of Economics, Faculty of Economics, Universitas Negeri Manado, Indonesia.

E-Mail: stannyrawung@unima.ac.id

2. Maya F. S. Salindeho obtained her Master's degree from Universitas Padjadjaran, Indonesia, in 1999. The author is an Assistant Professor at the Department of Economics, Faculty of Economics, Universitas Negeri Manado, Indonesia.

E-Mail: mayasalindeho@unima.ac.id 